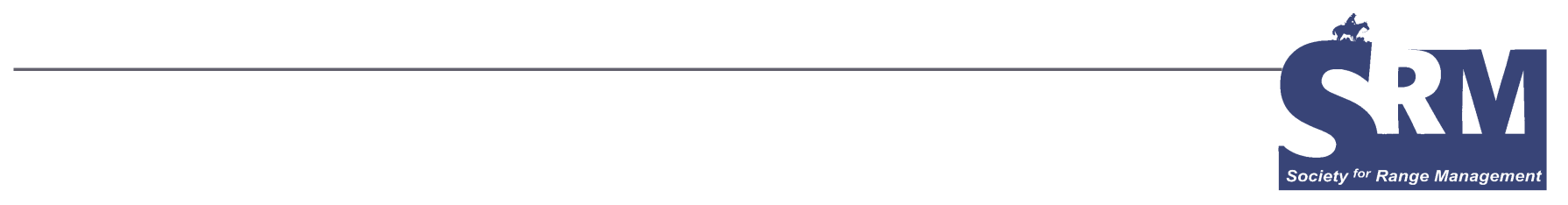

\title{
Planned Herbivory in the Management of Wildfire Fuels
}

\section{Grazing is most effective at treating smaller diameter live fuels that can greatly impact the rate of spread of a fire along with the flame height.}

\section{By Glenn Nader, Zalmen Henkin, Ed Smith, Roger Ingram, and Nelmy Narvaez}

W

ildfires are increasing in number, intensity, and size. Five of the most significant wildfire seasons in the United States since 1960 , as measured by total acres burned, have occurred since $2000 .{ }^{1}$ The vegetation or fuel profile, a major factor determining fire behavior, is studied in two aspects: vertical and horizontal arrangement, and amount. The vertical arrangement of fuel determines the degree of its mixture with air and, thus, flame height and duration of elevated heat. The continuity of horizontal fuel arrangement determines potential for fire spread across the landscape. These attributes, along with topography and weather conditions (wind and fuel moisture), are what determine the kind of wildfire that is going to occur. Many management and ecological conditions have allowed for the increased fuels. The increasing number of residences being built in forest and rangeland ecosystems provides more ignition sources and restricts the ability to manage fire. Introduction of exotic plants such as cheatgrass also has changed the fire behavior in many sagebrush plant communities. ${ }^{2}$

Fuel treatments are generally placed in two different categories. Fuel breaks are linear fuel modifications that are often situated along a road or ridge. They can range in width from 30 feet to 400 feet and are designed as a tool for fire fighters to stop fires. Landscape area treatments are designed to reduce flame height and change fire behavior over a large area. Long-term landscape treatment efforts are focused on changing the plant community to decrease the flame height when fire occurs. Both approaches require maintenance in order to remain valuable fire management tools. The objective for fuel reduction is to change fire behavior by impacting the following: fuel bed depth, fuel loading, percent cover, and ladder fuels that result in a fire flame less than four feet high. At that level all fire fighting management tools can be used, while maintaining fire fighter safety.

\section{Mechanized Treatments}

Mechanized treatments are used by land managers to alter or remove vegetation, including mowing, mastication, and biomass harvesting. Mastication involves the use of a large mechanized device for chopping, and is used in brush and trees to break up the fuel pattern and decrease combustibility by placing fuels on the ground. It changes fire behavior by rearranging the fuel profile through distributing some of the fuel on the ground. This action also causes a reduction of ladder fuels, which decreases potential for vertical extension of fire into tree canopies; crown fires are very difficult for fire fighters to control. Mastication can be used as a pretreatment followed by prescribed fire or grazing treatments. Some of the disadvantages of mastication are the cost of $\$ 350$ to $\$ 800$ per acre, ground disturbance, short life of the treatment in some areas, terrain and surface roughness limitations, and soil compaction. Mastication can 
result in death in some brush species, but many species resprout from the roots and require retreatment. Mechanized treatments also include the thinning of overstory vegetation through biomass harvesting. The harvested biomass is brought to a chipping unit and the resulting material is transported off the site for use in energy power plants. The sale of the biomass chips reduces the cost of this treatment. Thinning can provide desired conditions for both ladder fuels and crown spacing in one treatment. Soil moisture condition is the only limitation on the time of year that the treatment can be conducted. Disadvantages include transportation costs of hauling biomass and removal of nutrients from the ecosystem. In some cases, trees that are removed can be sold as commercial saw logs to offset fuel treatment costs. Mowing is generally used in grass communities to drop the fuel on the ground, where it has less contact with air and thus has lower combustibility. Mowing needs to be done during the end of the green season or it can cause fires from the blades striking rocks when dry grass is present. The costs of mowing range from $\$ 25$ to $\$ 40$ per acre.

\section{Herbicides}

Herbicides can be sprayed to kill specific plants, but this does not alter the fuel pattern immediately. Herbicide treatment of targeted species has a cost of $\$ 25$ to $\$ 250$ per acre. The disadvantages include concerns about its impact on the environment and short-term increases in fuel flammability.

\section{Prescribed Fire}

Prescribed fire can be used to change the fuel load and pattern. Prescribed burning can generally be achieved for less than $\$ 150$ per acre. It is most effective for reducing surface fuels 0-3 inches in stem diameter. Because of air quality concerns and the need for the correct fire weather conditions (wind, air, and plant humidity), there is usually a narrow time period in the season during which burning can be done. A mechanical or hand removal treatment might also be required prior to the reintroduction of fire into the ecosystem to achieve desired fire behavior. The disadvantages of this treatment are reduced aesthetics, tree mortality, impaired air quality, liability concerns, pretreatment costs where applicable, the requirement of qualified people who understand prescribed fire, and treatment variation (it might burn hotter or cooler than planned). Also, it might not be appropriate for some plant communities, such as low-elevation sagebrush, which can be replaced postfire by cheatgrass.

\section{Hand Cutting}

Hand cutting and stacking of fuels for burning is very labor-intensive and thus expensive. Costs range from $\$ 800$ to $\$ 2,300$ per acre, depending on amount of vegetation. It is the best alternative on steep slopes where mechanized equipment cannot operate.

\section{Grazing}

Grazing is best used when addressing the smaller diameter vegetation that makes up the 1- and 10-hour fuels. Onehour fuels are those fuels whose moisture content reaches equilibrium with the surrounding atmosphere within 1 hour and whose stems are less than one-fourth inch in stem diameter. Ten-hour fuels have stems that range from onefourth inch to 1 inch in stem diameter. Grazing can impact the amount and arrangement of these fuels by ingestion or trampling. It is a complex, dynamic tool with many plant and animal variables, and it requires sufficient knowledge of the critical control points to reach treatment objectives. Those control points involve the species of livestock grazed (cattle, sheep, goats, or a combination); the animals' previous grazing experience (which can affect their preferences for certain plants); time of year as it relates to plant physiology (animal consumption is directed by the seasonal nutrient content); animal concentration or stocking density during grazing; grazing duration; plant secondary compounds; and animal physiological state. Treatments either can be short-term to reduce flammable vegetation or longterm to change vegetation composition by depleting root carbohydrates in perennials and reducing the soil seed bank for annual plants. The objectives are to change the fire behavior through modification of the fuel bed, fuel loading, percent cover, and ladder fuels.

Depending on the plant community, the vegetation of concern or fuel will differ. The grazing approach to fuel treatment differs with the plant life cycle (annual or perennial). With annuals, the treatment is to remove plants while they are still green each year prior to fire season. Grazing before seed set can change seedbed dynamics, and with long-term implementation, grazing can change the species composition. For perennials, repeated grazing that depletes root carbohydrates and causes morality of targeted species is required to change plant composition. Root carbohydrate reserves are at their lowest level just after the period when plants initiate active shoot elongation. If plants are severely grazed early in the growing season, carbohydrate reserves are depleted, and plant vigor is reduced. ${ }^{3}$ Removal of bark or repeated defoliation are two other ways to destroy the plant. In brush species, the concept of changing the fuel profile the first year and managing it thereafter with grazing over large areas appears to be most sustainable.

Integration of different treatments could provide the best strategy. Livestock cannot effectively control mature brush plants that either grow higher than the animals can effectively graze or have large diameter limbs. Mastication, underburning, and hand-cutting can be used to manipulate the large-diameter, 100-hour brush fuels, and grazing can be used as a follow up treatment for controlling resprouting species or shifting the species composition to herbaceous plant fuel material. Tsiouvaras suggests that grazing followed by prescribed fire can be used safely to kill the aboveground parts of shrubs and further open the stand. ${ }^{4}$ Magadlela 
reported that adding cutting and herbicide use increased sheep effectiveness by reducing the brush below $20 \%$ in one year, but increased the costs. ${ }^{5}$

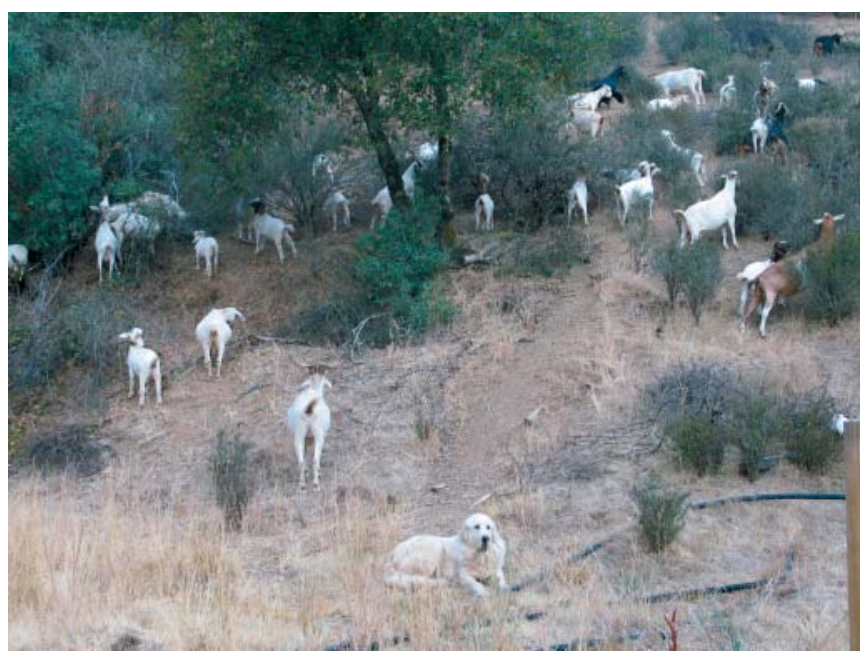

Goats grazing brush.

Prescribed grazing has the potential to be an ecologically and economically sustainable management tool for reduction of fuel loads. However, much of the information on grazing for fuel reduction is anecdotal. Limited scientific research information is available. Existing data indicate there are two ways by which grazing impacts the fuel load: removal of vegetation, and hoof incorporation of fine fuels. Smith et al. found that 350 sheep (ewes) grazing intensely on sagebrush/cheatgrass in a 2.5 -mile fuel break (divided into 20 pastures) in May in Nevada reduced fine fuels from 2,622 to 765 pounds per acre. ${ }^{6}$ Vegetative ground cover decreased $28 \%$ to $30 \%$, ground litter increased $20 \%$ to $23 \%$, and bare ground increased $4 \% .{ }^{6}$ Tsiouvaras studied grazing on a fuel break in a California Monterey pine and eucalyptus forest in the fall at a stocking rate of 113 Spanish goats per acre for 3 days; brush understory was reduced by $46 \%$ and $82 \%$ at 20 inches and 59 inches in height, respectively. Forage biomass utilization in the brush understory was $84 \%$. California blackberry showed the largest decrease in cover (73.5\%) followed by toyon, coyote brush, honeysuckle, herbaceous plants, and madrone. Poison oak and eucalyptus exhibited very little change. Goat grazing not only broke up the sequence of live fuels (horizontally and vertically up to 59 inches), but also reduced the amount of 1-hour dead fuels by $58.3 \%$, whereas the 100 -hour fuels remained constant. The litter depth was also reduced as much as $27.4 \%$ (from 2.9 inches before to 2 inches after grazing). Animal trampling resulted in crushing of fine fuels and mixing them into the mineral soil, thus reducing the chance of ignition. Green et al. grazed 400 goats on chaparral in July. ${ }^{7}$ The goats utilized $95 \%$ of the leaves and small twigs to 0.063 inches diameter from all the mountain mahogany plants. ${ }^{7}$ Use of scrub oak was $80 \%$, whereas use of chamise, eastwood manzanita, and California buckwheat was low, and Ceanothus was only taken under duress. ${ }^{7}$ Under "holding pen" conditions, use of less palatable species approached the use of palatable plants. ${ }^{7}$ Lindler reported that goats stocked at 7 per acre for 3 weeks in the summer in a ponderosa pine forest were estimated to remove $15 \%$ to $25 \%$ of the vegetation, depending on the plant species present and the length of stay in the pasture. ${ }^{8}$ The cost of the grazing treatment was $\$ 60$ to $\$ 70$ per acre. In comparison, herbicide costs on adjacent sites were $\$ 60$ to $\$ 125$ per acre, and $75 \%$ to $90 \%$ of the vegetation understory in the pine forest was removed. Intensive grazing by cattle to control shrub growth has been demonstrated as being useful for maintenance of fuel breaks. ${ }^{9-13}$ Perevolotsky et al. found that mechanical shrub removal and cattle grazing at the peak of green season in Israel 4 years in a row proved to be the most effective firebreak treatment. ${ }^{14}$ Heavy grazing for a short duration removed more than $80 \%$ of the herbaceous biomass, but reduced regeneration rate of shrubs for only 2 years. They stated that using goats or other browsing animals can increase the amount of shrub material removed by direct grazing, but can decrease actual physical damage to shrubs (cattle will trample and break more brush and graze less due to their size, whereas the opposite is true for goats). Henkin et al. found that under heavy grazing (71-83 cow grazing

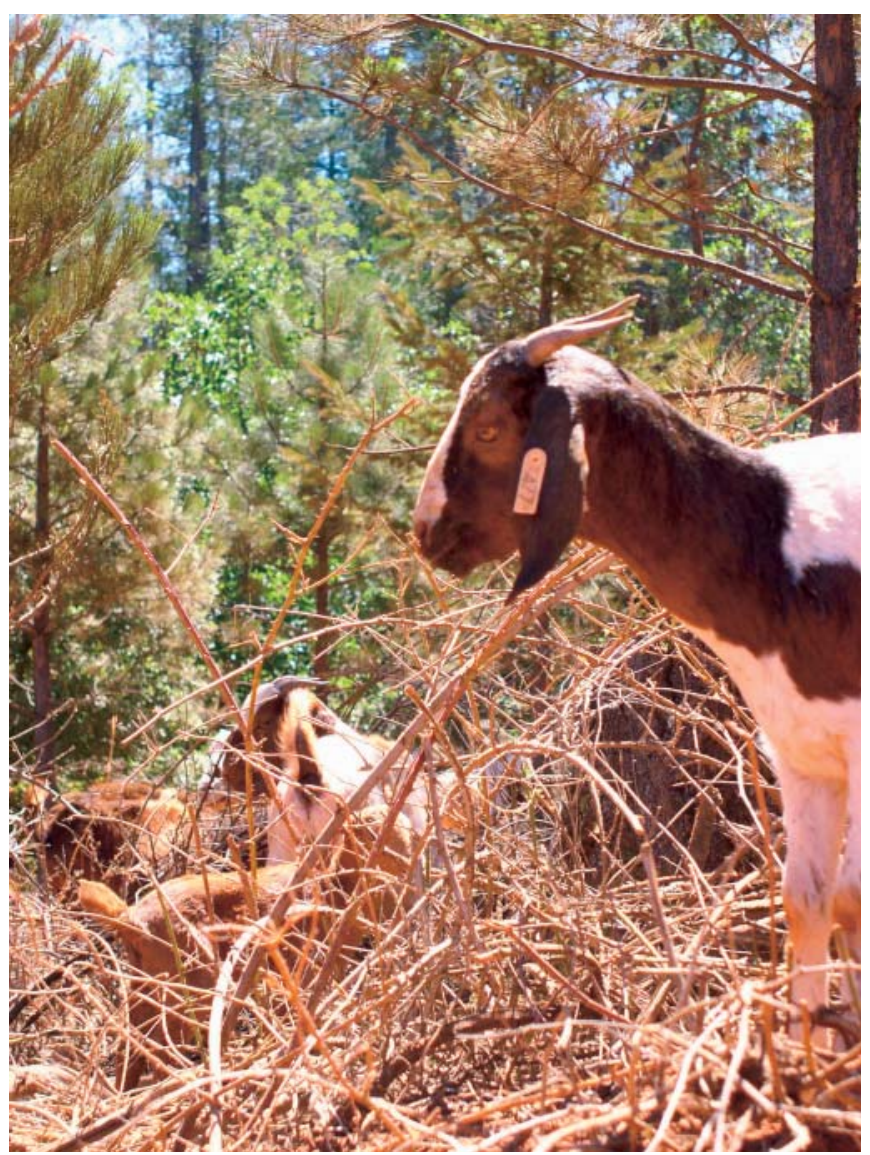

Goats grazing blackberry and other brush understory in a pine forest. 


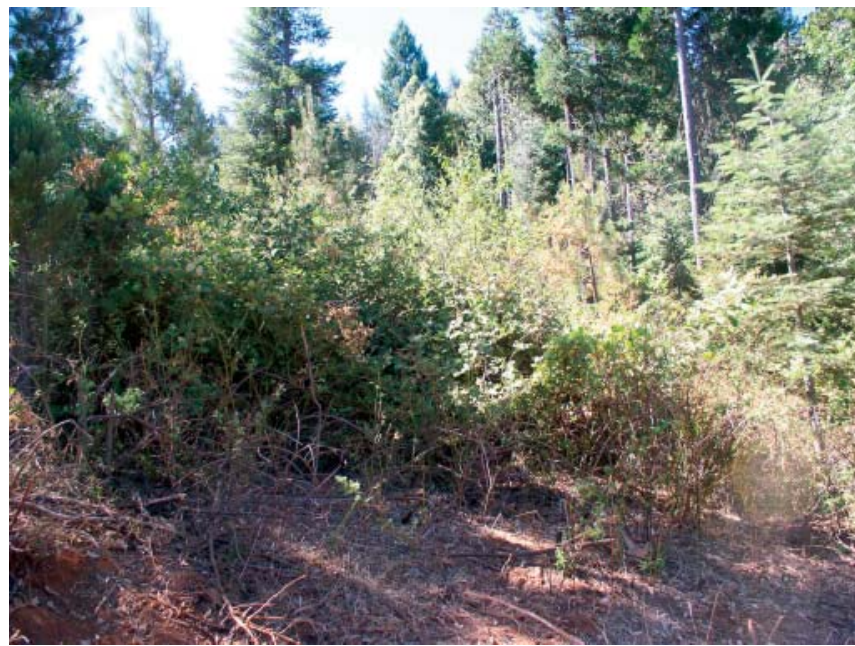

Edge of goat grazed area in Ponderosa forest.

days per acre), the basal regrowth of the oaks was closely cropped and the vegetation was maintained as predominantly open woodland. In the paddock that was grazed more moderately (49-60 cow grazing days per acre), the vegetation tended to return to dense thicket. ${ }^{12}$

Each species of animal has a unique grazing utilization pattern that is a function of mouth size and design, past grazing experience, and optimization of nutritional needs. ${ }^{15}$ The mouth size controls how closely animals are able to select and then graze a given surface. Animals also differ in their forage preferences and diet composition, thus when developing a fuel reduction grazing program, it is important to select the kind of livestock that will consume the desired species to alter the fire behavior. Provenza and Malechek showed a 50\% reduction of tannin in goat-masticated samples compared to unmasticated samples. ${ }^{16}$ This illustrates that goats can affect one of the secondary compounds that are present in some brush species, and thus can eat more of that species. When preferred forage is absent or unpalatable, grazing animals are capable of changing their food habitat.

\section{Table 1. Percent of time spent by animals feeding on diverse plant types in Texas ${ }^{17}$}

\begin{tabular}{|l|c|c|c|}
\hline \multirow{2}{*}{ Forage type } & \multicolumn{3}{|c|}{ Animal species } \\
\hline Grass & Cattle & Sheep & Goats \\
\hline Forbs & 78 & 53 & 50 \\
\hline Browse & 21 & 24 & 29 \\
\hline
\end{tabular}

Magadlela et al. found that goats grazing in Appalachian brush defoliated brush early and then grazed herbaceous material later in the seasons. ${ }^{5}$ Sheep preferred to graze herbaceous material first, but increased grazing pressure forced sheep to defoliate brush earlier in the season..$^{5}$ Goats reduced brush cover from $45 \%$ to $15 \%$ in one year. Sheep took 3 years to produce the same results. Brush clearing improved when goats followed sheep; total brush was reduced from $41 \%$ to $8 \%$ in one year. By the end of 5 years of goat grazing, the brush was reduced to $2 \%$ cover. Luginbuhl et al. found that multiflora rose was nearly eliminated from the Appalachian Mountains after 4 years of grazing by goats alone $(100 \%)$ or goats + cattle $(92 \%) .{ }^{18}$ Simultaneously, total vegetative cover increased with goats alone $(65 \%$ to $86 \%)$ and with goats + cattle $(65 \%$ to $80 \%)$, compared with the control plot where vegetation cover decreased from $70 \%$ to $22 \%$. Lombardi et al. studied the use of horses, cattle, and sheep in Northwest Italy for 5 years and found that grazing reduced woody species cover and stopped the expansion of shrub population. ${ }^{19}$ The impact varied with the type of animal. Cattle and horses had a higher impact on the plants through the damage caused by trampling. It was found that the effectiveness of control depended on palatability and tolerance of woody species to repeated disturbance. Juniper and rhododendron were reported not to have been grazed. Hadar et al. reported that the inconsistent response of some plants to grazing could be the interaction between grazing pressure and moisture conditions. ${ }^{13}$ They found that heavy cattle grazing (340-394 cow grazing days per acre) during 7 to 14 days at the end of the growing season decreased species richness because of consumption of seeds from the annual plants.

The time of the year that grazing occurs can influence the types of plants consumed, because it impacts the plant physiological status, which controls the nutritional value to the animal. Additionally, the time of year affects the plant's postgrazing mortality. Taylor reported studies using heavy grazing by sheep in Idaho showed that season of use impacted the utilization. ${ }^{17}$ Late-fall grazing reduced three-tip sagebrush, whereas grazing during spring increased sagebrush and decreased grasses.

Grazing impact can change with the density of animals and duration of grazing. The shorter the duration, the more even the plain of nutrition is. Over longer periods in a pasture, animals select the most nutritious forage first and consume less nutritious forage later. Stocking density has a great impact on the grazing consumption and trampling of fuels. Fences, herding, topography, slope, aspect, distance from water, placement of salt, and forage density all impact the distribution of animals and their use of the forage. By concentrating the animals into a smaller area for short periods of time, the preference for plants decreases and animals compete for the available forage. Increasing stocking density also increases hoof action and incorporation of the fine fuels into the ground. Spurlock et al. stated that high stocking rates with little supplementation forces goats to graze even less palatable species and plant parts, and as a result, much brush can be eradicated in 2-3 years. ${ }^{20}$ Lindler et al. suggests that a stocking rate of 15 goats per acre in a California pine forest is required to effectively treat understory brush. ${ }^{8}$ 


\begin{tabular}{l|c|c|c|}
$\begin{array}{l}\text { Table 2. Sheep diet consumption in Texas varied } \\
\text { with stocking rate }\end{array}$ \\
\hline & \multicolumn{4}{|c|}{ Forage type } \\
\hline Stocking rate & Browse & Grass & Forbs \\
\hline Light & 16 & 55 & 28 \\
\hline Heavy & 55 & 39 & 5 \\
\hline
\end{tabular}

\begin{tabular}{|c|c|c|c|}
\hline $\begin{array}{l}\text { Grazing } \\
\text { intensity }\end{array}$ & $\begin{array}{l}\text { Bare } \\
\text { soil }\end{array}$ & $\begin{array}{c}\text { Vegetation } \\
\text { cover }(\%)\end{array}$ & Litter \\
\hline Light & +6 & -22 & +25 \\
\hline Moderate & +4 & -28 & +20 \\
\hline Heavy & +4 & -30 & +23 \\
\hline
\end{tabular}

Hadar et al. reported that light grazing increased plant diversity on treated sites. ${ }^{13}$ Thus, when proposing a stocking rate for treatment consumption, the environmental impact needs to be considered.

Plants, over time, have developed mechanisms to limit or prohibit grazing. Launchbaugh et al. summarized this plant and animal interaction as follows: plants possess a wide variety of compounds and growth forms that are termed "anti-quality" factors because they reduce forage's digestible nutrients and energy or yield a toxic effect that deters grazing. ${ }^{22}$ Secondary compounds (eg, tannins, alkaloids, oxalates, terpenes) can control the plant-animal interactions that drive intake and selection. Animals might expel toxic plant material quickly after ingestion, secrete substances in the mouth or gut to render the compounds inert, or rely on the rumen microbes or the body to detoxify them. The species of livestock selected is important because some species can detoxify compounds or have a smaller mouth that allows them to eat around thorns; this allows them to still obtain nutritional or pharmaceutical products that aid in digestion and detoxification. Breeders can select for animal genetic lines that can adapt to these compounds. Tannins are the most important plant defensive compounds present in browse, shrubs, and legume forages. Concentrations in woody species vary with environment, season, plant developmental phase, plant physiological age, and plant part. Levels in excess of $50 \mathrm{~g} \cdot \mathrm{kg}^{-1} \mathrm{DM}$ can lead to low palatability, reduced digestibility, depressed voluntary feed intake, inhibition of digestive enzymes, and increased toxicity to rumen micro-organisms. ${ }^{23-27}$ In some cases, when the plant compound is known, it is possible to intercede. For example, polyethylene glycol (PEG), a polymer that binds tannins irreversibly, can be used to reduce the negative effects of tannins on food intake, digestibility, and preferences. ${ }^{28}$ For oxalates, calcium supplementation has shown to ameliorate the diet suppression. Launchbaugh et al. suggests that supplementation of protein, phosphorous, sulfur, and energy can also make a difference in intake of plant material containing secondary compounds. ${ }^{22}$ They even postulate that clay can be used to detoxify compounds. ${ }^{22}$

Grazing animals can effectively distinguish between plants that differ in digestible energy or nutrients. The animal's consumption is driven by its physiological state. Nonlactating animals have much lower nutrient requirements than lactating females or growing weaned animals and can consume a wider array of plants to meet nutritional needs. Animals can be forced to eat below their nutritional needs and they will balance their needs by using existing body fat and protein. The animal can tolerate short-term energy or protein deficits, but sustained periods at this status can be reason for concern. For this reason, lactating and young growing animals are not generally recommended for fire fuel control. In a system that is focused on maintaining the fuel profile, one can use growing animals in an annual brush grazing system that focuses on the annual new growth.

Because of the complexity of plant and animal interactions, a project evaluation should be developed that considers measurable and attainable objectives before grazing is used. It should include a review of treatment objectives, outcomes, and environmental impacts. This will dictate the kind of animal needed, grazing intensity, timing of the grazing event, and duration of the grazing period. Variation in animal-plant interaction is driven by forage type, grazing season, yearly season variation, animal interaction with the grazing system (animal density and competition), previous grazing experience, mixture of grazing animals, and pregrazing treatment (integrated approach). The treatment and resulting outcomes cannot conveniently be predicted and might require adaptive onsite management. Treatment standards include stubble height for grass, percent vegetation cover by brush, plant mortality, removal of 1- and 10-hour fuel, and fuel bed depth.

Any grazing plan designed for fuel reduction needs to consider the grazing impacts on parameters other than just simply reduction. The effects of the grazing management should be studied for their impact on water quality, compaction, riparian vegetation, disease interaction with wildlife (bluetongue, pasturella), and weed transmission. The positive aspects of grazing over other treatments also should be weighed, including recycling of nutrients into the products of food and fiber.

Grazing is best used when addressing vegetation with stems of smaller diameters that make up the 1- and 10-hour fuels. These two fuel classes are important because they can greatly impact the rate of spread of a fire, as well as flame height. Many fire managers have viewed grazing in the same context as other single-event mechanical fuel treatments. 
These grazing treatments have been expensive to implement because they have a physiological cost to the animal, and require higher costs (such as portable fencing) to reach fuel objectives in one year. Perhaps a sustainable use of grazing would be annual grazing of large areas following mechanical treatment. This provides improved nutrition by presenting smaller regrowth that is higher in nutrition; this allows animal performance to improve while maintaining a specific fuel profile in the grazing area.

There are many issues that need to be considered when examining grazing for fuel reduction. Grazing has a more varied outcome than the mechanical fuel reduction treatments. Until the grazing treatment is perfected into a fully understood tool, the dominant management strategy will be to force utilization by limiting nutrition and/or preference. There is a lack of scientific data available to help managers understand and control the many variables that influence the outcome of fuel removal, and thus reaching defined objectives will be more difficult. The objectives of the treatment must be well-defined and well-described. It is important to understand animal preference as well as proper timing in order to meet the objectives. Some have considered fuel reduction by grazing simply as a method to increase animals on public lands; thus a well-thought-out plan is important. Many do not trust agencies to administer a private sector contractor to conduct the treatment correctly; thus a contract needs to be well-defined within the parameters of the operator's control. In the past, fire managers were willing only to look at the short-term impacts and not the long-term health and fire safety of the site or the effects of a long-term grazing program. Consumptive use, such as grazing, might not be compatible with recreation land use in some areas. A survey by Smith et al. indicated that $90 \%$ of residents near a fuel break stated use of sheep was an acceptable method for fuel reduction. ${ }^{6}$ Only $10 \%$ felt that they were inconvenienced by the treatment. Some responses indicated misconceptions held by residents regarding grazing and grazing management methods; one such example was fear of possible electrocution of animals and humans by

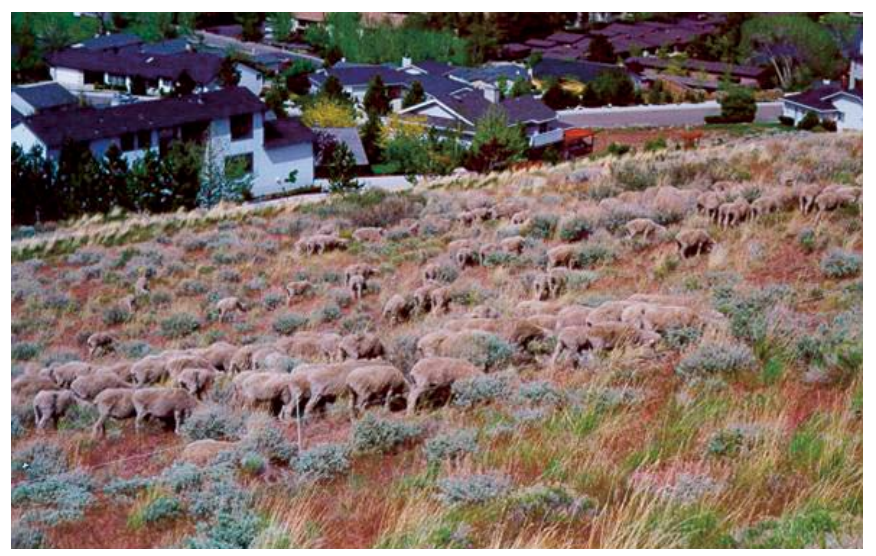

Sheep grazing a fuel break in Nevada. electric fences. These misconceptions by the public must be addressed when land managers make proposals for grazing.

\section{Conclusions}

Modification of wildfire fuels is an important issue in many regions of the world. At present, limited research knowledge exists to help guide managers in using grazing animals for fuel management. That knowledge is necessary to direct the timing and intensity of grazing to reach fuel management objectives similar to other methods. Also seasonal variation of nutrition content and secondary compounds of shrubs need to be further defined. Most of the grazing fuel modification study work has been conducted with goats, primarily because of their preference for targeted plant species. Grazing animals can modify wildfire fuels through consumption and trampling. Animals are most effective at treating smaller-sized live fuels and 1- and 10-hour fuels. These fuels influence an important part of fire behavior by providing the flammable material that creates a ladder of fuel in order for a fire to extend up from the ground into the brush and tree canopy. There is a lack of research knowledge upon which to draw in order to refine the grazing treatment to meet fuel management objectives. Many treatments in the past had only a single grazing year focus. This strategy can be effective in a grass ecosystem if timed right, but systems with abundant shrubs often require multiple years to create and maintain a fuel profile that is more desirable.

More research needs to be done to allow effective use of grazing as a fuel reduction tool. Further research also needs to be done on secondary compounds in brush plants, their seasonal variation, and methods to overcome them to achieve target utilization levels. Knowledge of the nutrient status of the plants throughout the year also will assist in indicating the time of optimum utilization of grazing in fire fuel reduction.

\section{References}

1. National Interagency Fire Center. 2006. Wildland Fire Statistics. Available at: http://www.nifc.gov/stats/index.html. Accessed January 2006.

2. Davidson, J. 1996. Livestock grazing in wildland fuel management programs. Rangelands 18:242-245.

3. Doescher, P. S., S. D. Tesch, and M. Alejandro-Castro. 1987. Livestock grazing: a silvicultural tool for plantation establishment. Journal of Forestry 85(10):29-37.

4. Tsiouvaras, C. N., N. A. Havlik, and J. W. Bartolome. 1989. Effects of goats on understory vegetation and fire hazard reduction in a coastal forest in California. Forest Science 35:1125-1131.

5. Magadlela, A. M., M. E. Dabaan, W. B. Bryan, and E. C. Prigge. 1995. Brush clearing on hill land pasture with sheep and goats. Journal of Agronomy and Crop Science 174:1-8.

6. Sмith, E., J. Davidson, H. Glimp. 2000. Controlled sheep grazing to create fuelbreaks along the urban-wildland 
interface. Proceedings of the 53rd Annual Meeting of the Society of Range Management; Boise, ID. 6 p.

7. Green, L. R., C. L. Hughes, and W. L. Graves. 1987. Goats control of brush regrowth on Southern California fuel-breaks. In First International Rangeland Congress; 14-18 August 1987; Denver, CO. p. 451-455.

8. Lindler, D., J. Warshawer, and D. Campos. 1999. Using goats to control understory vegetation. Forest Vegetation Management Conference 20:33-46.

9. Allen, B. H., And J.W. Bartolome. 1989. Cattle grazing effects on understory cover and tree growth in mixed conifer clearcuts. Northwest Science 63:214-220.

10. Gutman, M., Z. Henkin, Z. Holzer, I. Noy-Meir, and N. G. Seligman. 1991. Beef cattle grazing to create firebreaks in a Mediterranean oak maquis in Israel. In Proceedings of the IV International Rangeland Congress, Montpellier, France. p. 204-209.

11. Masson, P., and C. Guisset. 1993. Herbaceous and shrubby vegetation evolution in grazed cork oak forest firebreaks sown with subterranean clover and perennial grasses. In Proceedings of the 7th Meeting FAO European Sub-network on Mediterranean Pastures and Fodder Crops, Crete. p. 201-205.

12. Henkin, Z., M. Gutman, H. Aharon, A. Perevolotsky, E. D. Ungar, and N. G. Seligman. 2005. Suitability of Mediterranean oak woodland for beef herd husbandry. Agriculture, Ecosystems and Environment 109:255-261.

13. Hadar, L., I. Noy-Meir, and A. Perevolostsky, 1999. The effect of shrub clearing and intensive grazing on the composition of a Mediterranean plant community at the functional group and species level. Journal of Vegetation Science 10:673-682.

14. Perevolotsky, A., R. Schwartz-Tzachor, and R. YonAtan. 2002. Management of fuel breaks in the Israeli Mediterranean ecosystem. Journal of Mediterranean Ecology 3(2-3):13-22.

15. Bелsоm, S. L. 1980. Dietary overlap between cattle, domestic sheep, and pronghorns. In R. E. Soesbee and F. S. Guthery [eds.]. Noxious Brush and Weed Control Research highlights. Volume 11. Lubbock, TX: Texas Tech University. p. 40-41.

16. Provenza, F. D., And J. C. Malechek. 1984. Diet selection by domestic goats in relation to blackbush twig chemistry. Journal of Applied Ecology 21:831-841.

17. TAylor, C. A. 1994. Sheep grazing as a brush and fine fuel management tool. Sheep Research Journal 10:92-96.

18. Luginbuhl, J. M., T. E. Harvey, J. T. Green, M. H. Poore, ANd J. P. Mueller. 1999. Use of goats as a biological agents for the renovation of pastures in the Appalachian region of the United States. Agroforestry Systems 44:241-252.

19. Lombardi, G., A. Reyneri, and A. Cavallero. 1999. Grazing animals controlling woody-species encroachment in subalpine grasslands. In Proceedings of the International
Occasional Symposium of the European Grassland Federation; 27-29 May 1999; Thessaloniki, Greece. p. 85-90.

20. Spurlock, G. M., R. Plaister, W. L. Graves, T. E. Adams, And R. Bushnell. 1980. Goats for california brushland. Oakland, CA: Cooperative Agriculture Extension, University of California, Leaflet 21044. 30 p.

21. Kothmann, M. M. 1968. The botanical composition and nutrient content of the diet of sheep grazing on poor condition pasture compared to good condition pasture [dissertation]. College Station, TX: Texas A\&M University. 68 p.

22. Launchbaugh, K. L., F. D. Provenza, and J. A. Pfister. 2001. Herbivore response to anti-quality factors in forages. Journal of Range Management 54:431-440.

23. Robbins, H., A. E. Hagerman, O. Hajeljord, D. L. Baker, C. C. Schwartz, and W. W. Moutz. 1987. Role of tannins in defending plants against ruminants: reduction in protein availability. Ecology 68:98-107.

24. Happe, P. J., K. J. Jenkins, E. E. Starkey, and S. H. Sharrow. 1990. Nutritional quality and tannin astringency of browse in clear-cuts and old-growth forest. Journal of Wildlife Management 54:547-556.

25. Kumar, R., and S. Vaithyanathan. 1990. Occurrence nutritional significance and effect on animal productivity of tannins in tree leaves. Animal Feed Science Technology 30:21-38.

26. Lowry, J. B., C. S. McSweeney, and B. Palmer. 1996. Changing perceptions of the effect of plant phenolics on nutrient supply in the ruminant. Australian Journal of Agriculture Research 47:829-842.

27. Bryant, J. P., F. D. Provenza, J. Pastor, P. B. Reichardt, T. P. Clausen, and J. T. Du Toit. 1991. Interactions between woody plants and browsing mammals mediated by secondary metabolites. Annual Review of Ecology and Systematics 22:431-446.

28. Villalba, J. J., F. D. Provenza, and R. E. Banner. 2002. Influence of macronutrients and polyethylene glycol on intake of a quebracho tannin diet by sheep and goats. Journal of Animal Science 80:3154-3164.

Authors are: Livestock $\Xi^{2}$ Natural Resources Advisor, University of California Cooperative Extension, 142-A Garden Hwy, Yuba City, CA 95991, ganader@ucdavis.edu (Nader); Research Leader Range Management, Agricultural Research Organization, The Volcani Center, PO Box 6, Bet Dagan, Israel (Henkin); Natural Resource Specialist, University of Nevada Cooperative Extension, PO Box 338, Minden, NV 89423 (Smith); Livestock E Natural Resources Advisor, University of California Cooperative Extension, 11477 E Ave, Auburn, CA 95603 (Ingram); and PhD Candidate in Ecology, Ecology Graduate Group, Animal Science Department, University of California, Davis (Navaraez). 